Maria Zboralska

\title{
„WYBRAĆ WIĘKSZĄ WOLNOŚĆ”
}

\author{
NOWY HUMANIZM JANA PAWŁA II
}

W październiku 2008 roku zorganizowano w Rzymie międzynarodowe sympozjum naukowe pt. Chrystus - Kościót - Człowiek, upamiętniające 30-lecie wyboru Karola Wojtyły na Stolicę Piotrową. Jeden z prelegentów, ceniony biograf polskiego papieża, prof. George Weigel, wygłosił wówczas referat pod znamiennym tytułem Nowy humanizm Jana Pawła II. Temat wystąpienia w moim odczuciu doskonale odzwierciedlał to, co w myśli filozoficznej i teologicznej papieża $\mathrm{z}$ dalekiego kraju było najistotniejsze, mianowicie tajemnicę człowieka, a jednocześnie podkreślał ożywczą świeżość jego spojrzenia. Spojrzenia, które - co szczególnie warto podkreślić - wyklarowało się przede wszystkim w „krakowskim” okresie życia następcy św. Stanisława BM.

Wezwanie do tworzenia „nowego humanizmu” sam św. Jan Paweł II skierował do młodzieży we Florencji 19 października 1986 roku. Podczas rozważań towarzyszących modlitwie Anioł Pański papież powiedział: „Trzeba zapoczątkować nowy humanizm, w którym cenne osiągnięcia czasów współczesnych zostaną zintegrowane z trwałymi wartościami chrześcijańskimi” ${ }^{1}$. Zdanie to wypowiedział w kontekście niebezpieczeństwa zatrzymania się na materialnym wymiarze postępu cywilizacyjnego i technologicznego bez odwołania się do głębi ducha ludzkiego, do wymiaru moralnego i duchowego człowieka. Jednak z zaproponowanym określeniem „nowego humanizmu” (podobnie zresztą jak z innymi podobnymi określeniami św. Jana Pawła II - „nową ewangelizacją”, „nowym feminizmem” czy „nową wyobraźnią miłosierdzia”) jest tak, że na próżno szukalibyśmy w jednym tekście papieskim wszystkich założeń jego koncepcji. Ojciec święty raczej

${ }^{1}$ Jan Paweł II, Wspólnie realizujcie projekt humanizacji świata, Florencja, 19.10.1986, [w:] Jan Paweł II, Podręcznik Pokolenia Jana Pawła II, wstęp J. Góra, red. H. Koźmińska, Poznań 2008, s. 279. 
wywoływał dany temat niż przedstawiał od razu jego syntezę, pozostawiając trud zgłębiania go tym, którzy zechcą w poszukiwaniu źródła „iść do góry, pod prąd”.

W kontekście nowego humanizmu ta prawdziwie wymagająca dla badaczy wędrówka wynika przede wszystkim z mnogości pism antropologicznych Karola Wojtyły, wielowątkowości jego myśli czy hermetycznego nieraz języka wypowiedzi. Stąd też komentatorzy myśli polskiego papieża uciekają się często do słów-kluczy, za pomocą których próbują ukazać, co w tej refleksji było najistotniejsze. Wydaje się, że taką hermeneutykę warto zastosować nawet w tak krótkim, jak niniejszy, tekście. Zanim jednak zostaną zaproponowane trzy najważniejsze pojęcia nowego humanizmu Jana Pawła II, warto zwrócić uwagę na pewne podstawowe reguły, którymi rządzi się jego myśl.

\section{Antropologia adekwatna i etyka}

Od początku pragnieniem Karola Wojtyły - Jana Pawła II było możliwie najpełniejsze ujęcie misterium hominis. Głosząc na progu pontyfikatu słynne katechezy o teologii ciała, swoją wizję człowieczeństwa nazwał antropologią adekwatną, która - jak wyjaśniał wiernym zebranym na Placu św. Piotra w Rzymie - „stara się rozumieć i tłumaczyć człowieka w tym, co istotowo ludzkie (...). Antropologia «adekwatna» pozostaje na gruncie istotowo «ludzkiego» doświadczenia, opierając się redukcjonizmowi typu "przyrodniczego»"3.

W tym dwuzdaniowym fragmencie pobrzmiewa echo polemik, jakie Karol Wojtyła prowadził szczególnie w latach 50.-70. XX wieku, kiedy to próbował przekonać słuchaczy i czytelników, że nie można postawić znaku równości pomiędzy światem wszystkich bytów żyjących a człowiekiem. Osoba ludzka jest „kimś więcej i kimś bardziej" niż roślina czy zwierzę. Przede wszystkim człowiek ma rozum i wolną wolę, które stanowią o nieredukowalności osoby do świata przyrody. Jednak człowiek argumentował dalej Wojtyła - to nie tylko jak chciał Arystoteles animal rationale (zwierzę rozumne) ani też tylko individua substantia rationalis naturae (indywidualna substancja o racjonalnej naturze) - jak pisał Boecjusz. Osoba - tłumaczył Wojtyła (a można w tych słowach dopatrzeć się jego fascynacji mistyką św. Jana od Krzyża, któremu poświęcił pracę doktorską ${ }^{4}$ oraz filozofią fenomenologiczną,

\footnotetext{
${ }^{2}$ Jan Paweł II, Tryptyk rzymski. Medytacje, Kraków 2003, s. 11.

${ }^{3}$ Jan Paweł II, Mężczyznq i niewiasta stworzyt ich, red. S. Dziwisz, J. Kowalczyk, T. Rakoczy, Città del Vaticano 1986, s. 54-55.

${ }^{4}$ K. Wojtyła, Zagadnienie wiary w dziełach św. Jana od Krzyża, Kraków 1990.
} 
której dotyczyła jego rozprawa habilitacyjna ${ }^{5}$ - to również wnętrze, świat przeżyć wewnętrznych. To jedyność i niepowtarzalność osoby ludzkiej, jej podmiotowość

Karol Wojtyła przekonywał zatem, że dopiero synteza definicji kosmologicznej (człowiek jako przedmiot wśród innych przedmiotów żyjących) i personalistycznej (człowiek jako podmiot) daje pełen obraz tajemnicy człowieka. Tajemnicy, z którą współczesny świat, nie do końca się identyfikuje. 2 kwietnia 1980 roku papież nie bez bólu przyznał:

Jesteśmy (...) dziećmi epoki, w której (...) integralna wizja człowieka w wyniku postępu wielu różnych nauk z łatwością może być wyparta i zastąpiona przez różne ujęcia cząstkowe, które zatrzymując się na takim lub innym aspekcie compositum humanum nie dosięgają integrum człowieka lub pozostawiają je poza swoim polem widzenia. Z kolei zaś włączają się w to różnorodne trendy cywilizacyjne epoki, które na tych cząstkowych prawdach o człowieku budują swoje propozycje i wskazówki praktyczne co do ludzkiego postępowania, a częściej jeszcze na temat tego, jak postępować „Z człowiekiem". Człowiek wówczas staje się bardziej przedmiotem określonych technik niż podmiotem odpowiedzialnym za własne działanie. ${ }^{7}$

To stwierdzenie, w którym pobrzmiewa troska o wymiar moralny osoby ludzkiej, podprowadza nas pod drugą regułę, rządzącą namysłem nad człowiekiem w ujęciu Karola Wojtyły. Zasada ta mówi o ścisłym związku między antropologią a etyką: $\mathrm{z}$ faktu godności człowieka ma wynikać w praktyce postępowanie na miarę tej godności. Dla Jana Pawła II pytanie: „kim jestem?” prowadzi zatem automatycznie do pytania: ,jak mam żyć?”. Przykładowym zdaniem wyrażającym tę logikę jest to z 17 punktu adhortacji apostolskiej Familiaris consortio: „Rodzino, stań się tym, czym jesteś” ". Inaczej mówiąc, skoro rodzina jest wspólnotą życia i miłości na wzór Trójcy Świętej, to zadaniem jej członków jest nieustanne budowanie i pogłębianie tej komunii. Stąd też nie dziwi komentarz księdza prof. Tadeusza Stycznia dotyczący środowych katechez Jana Pawła II, traktujących, podobnie jak cytowana adhortacja, o powołaniu człowieka do miłości:

${ }^{5}$ Tytuł rozprawy: Próba opracowania etyki chrześcijańskiej według systemu Maxa Schelera, wyd. drukowane: K. Wojtyła, Ocena możliwości zbudowania etyki chrześcijańskiej przy założeniach systemu Maxa Schellera, Lublin 1959.

${ }^{6}$ Por. Jan Paweł II, Człowiek jest osoba, [w:] Jan Paweł II, Osoba i czyn oraz inne studia antropologiczne, Lublin 2000, s. 415-420; Jan Paweł II, Podmiotowość i „to, co nieredukowalne” w człowieku, [w:] Jan Paweł II, Osoba i czyn..., s. 433-443.

${ }^{7}$ Jan Paweł II, Osoba i czyn..., dz. cyt., s. 94-95.

${ }^{8}$ Jan Paweł II, adh. Familiaris consortio, 17. 
„Teologia ciała” Jana Pawła II jest próbą nakreślenia możliwie pełnej wizji c zło w i e $\mathrm{k}$ a na podstawie objawienia, jest więc przede wszystkim a n tropologią, antropologią te ologiczną. Równocześnie antropologia ta posiada wymiar wybitnie etyczny: logos człowieka, który okazuje się logosem daru, przechodzi etos daru. ${ }^{9}$

Z wymaganiami działania na miarę godności osoby ludzkiej spotykamy się również we fragmencie Listu Ojca Świętego do artystów opublikowanego w 1999 roku. Papież, komentując w nim prawdę o stworzeniu człowieka i poleceniu czynienia sobie ziemi poddanej (por. Rdz 1, 27-28), tak pisał:

Nie wszyscy są powołani, aby być artystami w ścisłym sensie tego słowa. Jednak według Księgi Rodzaju, zadaniem każdego człowieka jest być twórcą własnego życia: człowiek ma uczynić z niego arcydzieło sztuki. ${ }^{10}$

Czytając te słowa z perspektywy zamkniętej już księgi dni Jana Pawła II, nie sposób nie podziwiać arcydzieła, jakie ten święty człowiek uczynił ze swojego życia. Taki właśnie odbiór osoby następcy św. Piotra przełomu XX i XXI wieku potwierdzają tysiące wiernych $\mathrm{z}$ całego świata zatrzymujących się co dzień przy grobie polskiego papieża w rzymskiej bazylice św. Piotra. Wręcz symbolicznego wymiaru nabiera ta liczna obecność pielgrzymów gromadzących się przy jego doczesnych szczątkach w porównaniu do cieszącej się mniejszym zainteresowaniem Piety dłuta genialnego Michała Anioła, eksponowanej w sąsiedniej kaplicy. Tak jakby ludzie wiedzeni intuicją bardziej potrafili w pięknym człowieczeństwie papieża rozpoznać prawdziwe arcydzieło sztuki niż w wybitnym przecież dziele renesansowego twórcy.

Obserwacja niezwykłego fenomenu z bazyliki św. Piotra prowadzi w sposób naturalny do pytania: co było kluczem do spełnionego życia Karola Wojtyły - Jana Pawła II? A szerzej: kim według niego jest człowiek i jak, w jaki sposób ma żyć?

\section{W kręgu umysłu, woli i serca}

Tekstem, wskazującym słowa-klucze nowego humanizmu Wadowiczanina jest dość mało znana homilia ojca świętego wygłoszona w Częstochowie do alumnów,

${ }^{9}$ T. Styczeń, Ciało jako „znak obrazu Stwórcy”, [w:] Jan Paweł II, Mężczyzna i niewiasta stworzyt ich. Chrystus odwołuje się do „początku”. O Jana Pawła II teologii ciała, red. T. Styczeń, Lublin 2001, s. 89.

${ }^{10}$ Jan Paweł II, List do artystów, 2. 
młodzieży zakonnej i służby liturgicznej 6 czerwca 1979 roku. Papieskie rozważania osnute były wokół fragmentu Ewangelii o cudzie w Kanie Galilejskiej (por. J2, 1-12) i dotyczyły przede wszystkim problematyki pracy uczniów Chrystusa nad sobą, którą Jan Paweł II określił mianem „najwspanialszej działalności człowieka”"11. Wówczas też z ust następcy św. Piotra padły słowa o konieczności „rzetelnego przygotowania umysłów, woli i serc"12. Umysł, wola i serce - czyli innymi słowy: prawda, wolność i miłość - oto trzy najważniejsze słowa nowego humanizmu Jana Pawła II. Pojęcia, którym czas przyjrzeć się bliżej.

Pierwszym terminem wartym przestudiowania jest prawda. O tym, jak wielką wagę papież przywiązywał do tej kategorii, świadczy choćby jego rozmowa $\mathrm{z}$ André Frossardem. Na pytanie francuskiego dziennikarza o najważniejsze zdanie z Pisma Świętego, Jan Paweł II odpowiedział: „Poznajcie prawdę, a prawda was wyzwoli" (J 8, 32) ${ }^{13}$. Ojciec święty poszukiwanie prawdy uważał za podstawowy rys człowieczeństwa. Tym samym wyrażał wiarę w sens jej zgłębiania, a kryzys prawdy i sensu oraz brak zaufania do zdolności rozumu człowieka uważał za bardzo niebezpieczne dla kultury, gdyż wypływają z nich sceptycyzm, agnostycyzm, relatywizm i nihilizm ${ }^{14}$.

W 1964 roku arcybiskup Karol Wojtyła przekonywał uczestników uroczystości 600-lecia Uniwersytetu Jagiellońskiego, że człowiek jako istota obdarzona rozumem, umysłem jest „uzdolnioną i niejako skazaną na to, ażeby szukać prawdy, ażeby do niej dążyć, ażeby nią żyć"15. To związanie osoby ludzkiej z prawdą - tłumaczył metropolita krakowski - wynika $\mathrm{z}$ faktu bycia stworzonym na obraz i podobieństwo Boga (por. Rdz 1, 27-28), który jest prawdą i który prawdę w pełni posiada. Oznacza to, iż sam człowiek nie jest twórcą prawdy, lecz jej odkrywcą: „Człowiek ma żywą świadomość, iż prawda jest poza i «ponad»nim samym. Człowiek nie tworzy prawdy, ale ona sama się przed nim odsłania, gdy jej szuka wytrwale" ${ }^{\prime 6}$.

Pełnia prawdy, którą człowiek winien w przeciągu swojego życia zgłębiać i która stoi u podstaw ludzkiej kultury - argumentował dalej arcybiskup Wojtyła - to nie tylko prawda w porządku naturalnym, ale i nadprzyrodzonym ${ }^{17}$. Obrazowe zdanie ilustrujące tę myśl znajdziemy w opublikowanej ponad 20 lat później encyklice

${ }^{11}$ Jan Paweł II, Homilia w czasie Mszy św. odprawionej dla alumnów, młodzieży zakonnej i służby liturgicznej, Czętochowa, 06.06.1979, [w:] Jan Paweł II, Pielgrzymki do ojczyzny. Przemówienia, homilie, Kraków 2005, s. 114.

${ }^{12}$ Jan Paweł II, Homilia w czasie Mszy św. odprawionej dla alumnów..., dz. cyt., s. 113.

${ }^{13}$ A. Frossard, Portret Jana Pawła II, Kraków 1990, s. 72.

${ }^{14}$ Por. Jan Paweł II, Fides et ratio, 46-47, 81.

${ }^{15} \mathrm{~K}$. Wojtyła, Z kazania na 600-lecie Uniwersytetu Jagiellońskiego w kościele św. Anny w Krakowie, [w:] K. Wojtyła, „Aby Chrystus się nami postugiwał”, Kraków 1979, s. 203.

${ }^{16}$ Jan Paweł II, Przemówienie wygłoszone z okazji sześćsetlecia Wydziału Teologicznego Uniwersytetu Jagiellońskiego, Kraków, 08.06.1997, [w:] Pielgrzymki do ojczyzny..., dz. cyt., s. 986-987.

${ }^{17}$ Por. K. Wojtyła, Z kazania na 600-lecie Uniwersytetu Jagiellońskiego..., dz. cyt., s. 204. 
Fides et ratio, w której czytamy: „Wiara i rozum są jak dwa skrzydła, na których duch ludzki unosi się ku kontemplacji prawdy"18. Pochwała ludzkiego rozumu, zachęta do rozwijania umysłu nie może zatem być oderwana od prawd Bożych. I vice versa: „Odpowiedzią na odwagę (parresia) wiary musi być odwaga rozumu"19 - konkludował autor encykliki.

Bez wątpienia św. Jan Paweł II był osobą, łączącą w sobie harmonijnie poznawanie na drodze wiary i rozumu oraz pragnienie zaspokojenia głodu prawdy. Trudno nie wspomnieć tutaj formacji intelektualnej Karola Wojtyły na wyższych uczelniach: w Uniwersytecie Jagiellońskim w Krakowie, Angelicum w Rzymie oraz Katolickim Uniwersytecie Lubelskim. Jego dążenie do zgłębiania prawdy i niezwykła pamięć imponowały i zaskakiwały także podczas pielgrzymek do ojczyzny. Bo czyż nie robiły wrażenia cytowane a vista po kilkudziesięciu latach na wadowickim rynku fragmenty Antygony Sofoklesa? Albo czy niejednego turysty nie zawstydziła papieska znajomość tras beskidzkich, nazwana potem lekcją geografii ze Starego Sącza? A przecież nie tylko w tych sytuacjach, ale i w całym swoim życiu Karol Wojtyła potwierdzał słowa wypowiedziane w Łowiczu w 1999 roku, że „Prawdziwie wielki jest ten człowiek, który chce się czegoś nauczyć” ${ }^{20}$.

Drugim, obok veritatis splendor (blasku prawdy), filarem antropologii Wadowiczanina jest wolność. Ona także, jako wyraz stworzenia człowieka na obraz i podobieństwo Boże (por. Rdz 1, 27-28), świadczy o wyższości osoby ludzkiej nad innymi bytami. W myśli filozoficznej Karola Wojtyły wolność, a precyzyjniej mówiąc, chętnie używany przez niego termin „samostanowienie”, zajmowała bardzo ważne miejsce. „Samostanowieniu odpowiada stawanie się człowieka jako człowieka" ${ }^{21}$ - czytamy w artykule Osobowa struktura samostanowienia z 1978 roku. Aby zrozumieć sens tego zdania, trzeba przypomnieć podstawowe rozróżnienie, przedstawione przez autora w książce Osoba i czyn. Pisząc o dynamizmach, istniejących w człowieku, Wojtyła oddzielał doświadczenie określone jako „ja działam” od „coś się we mnie dzieje”. O ile bowiem to pierwsze wyraża wolny i świadomy czyn człowieka, o tyle to drugie akcentuje mechanizmy, dokonujące się bez udziału ludzkiej woli, a bez których organizm nie mógłby prawidłowo funkcjonować. Karola Wojtyłę jako antropologa bardziej interesowały oczywiście te pierwsze, świadczące o prymacie człowieka w świecie. W Osobie i czynie pisał:

\footnotetext{
${ }^{18}$ Jan Paweł II, Fides et ratio, wstęp.

${ }^{19}$ Jan Paweł II, Fides et ratio, 48.

${ }^{20}$ Jan Paweł II, Homilia w czasie Mszy św., Łowicz, 14.06.1999, [w:] Jan Paweł II, Pielgrzymki do ojczyzny..., dz. cyt., s. 1146.

${ }^{21} \mathrm{~K}$. Wojtyła, Osobowa struktura samostanowienia, [w:] K. Wojtyła, Osoba i czyn..., dz. cyt., s. 428 .
} 
Dynamizmowi na poziomie natury przeciwstawia się dynamizm na poziomie osoby właśnie poprzez fakt samostanowienia jako podstawy, z której wynika samo działanie, jego kierunek oraz celowość. W dynamizmie na poziomie natury brak tej szczególnej zależności od własnego „ja”, która cechuje dynamizm osoby. ${ }^{22}$

Karol Wojtyła dlatego posługiwał się pojęciem samostanowienia, ponieważ jego zdaniem doskonale odsłaniało ono podwójną rzeczywistość związaną z fenomenem ludzkiej wolności. Z jednej strony bowiem, mowa jest o tym, że „ja sam” stanowię, czyli jestem samozależny (nikt nie może za mnie chcieć, nikt nie może za mnie dokonywać wyborów). Z drugiej zaś strony, w sformułowaniu „stanowię (o sobie)" podkreślony zostaje aspekt wpływu na kształt własnego życia. Stąd też konkludował kierownik Katedry Etyki KUL:

W pojęciu samostanowienia zawiera się więcej niż w pojęciu sprawczości: człowiek nie tylko jest sprawcą swoich czynów, ale przez te czyny jest zarazem w jakiś sposób „twórcą samego siebie”23

Człowiek jako twórca, czyli jako ten, który - jak pamiętamy z Listu do artystów - ma uczynić ze swojego życia arcydzieło sztuki, dokonuje rzeźbienia materii swojego człowieczeństwa przede wszystkim w sumieniu. Dla Wojtyły filozofa sumienie jest miejscem, w którym „transcendencja wolności przechodzi w transcendencję moralności”24, zaś dla papieża Jana Pawła II jest ono „świętą przestrzenią, w której Bóg przemawia do człowieka”25. Niezależnie od języka opisującego tę rzeczywistość, wielka rola i godność sumienia polega na tym, że to w nim dokonuje się wybór dobra poznanego w świetle prawdy i prowadzącego do spełnienia się człowieka jako osoby. I oczywiście, o ile w sumieniu można dokonać także wyboru zła, i tym samym skazać się na niespełnienie, o tyle - na co zwracał uwagę George Weigel - „wolność dla papieża nie polega na robieniu tego, co się chce, lecz na dobrowolnym wybieraniu tego, co naprawdę dobre"26.

To zdanie jest prawdziwe także w obliczu wyboru bonum arduum (trudnego dobra). Jan Paweł II podkreślał, że dzięki wsparciu Ducha Świętego, który jest „najwyższym przewodnikiem człowieka: światłem ducha ludzkiego”, człowiek jest w stanie pokonać pokusy, nawet wówczas, kiedy wierność przykazaniom Bożym wydaje się po ludzku niemożliwa. To jest ciekawy wątek myśli Karola Wojtyły: mocne przekonanie, że człowiek nawet w bardzo trudnej sytuacji z Bożą pomocą

${ }^{22}$ K. Wojtyła, Osoba i czyn, [w:] K. Wojtyła, Osoba i czyn..., dz. cyt., s. 162.

${ }^{23} \mathrm{~K}$. Wojtyła, Osobowa struktura samostanowienia, dz. cyt., s. 427-428.

${ }^{24}$ K. Wojtyła, Osoba i czyn, dz. cyt., s. 199.

${ }^{25}$ Jan Paweł II, enc. Veritatis splendor, 58.

${ }^{26}$ G. Weigel, Kres i początek, tłum. M. Romanek, Kraków 2012, s. 446. 
jest w stanie wybrać dobro. Skrajnym przykładem dla Jana Pawła II są tu świadectwa męczenników, oddających życie za wierność prawdzie.

W tym kontekście możemy też zapytać, czy takim trudnym wyborem nie było dla krakowskiego metropolity przyjęcie decyzji konklawe 16 października 1978 roku, którą po latach, w 2002 roku, na krakowskich Błoniach nazwał wszak nie inaczej jak „wyrokiem”? Albo czy nie było nim pełne pokory zaakceptowanie związanych z chorobą ograniczeń ciała, gdy na kilka tygodni przed śmiercią zabieg tracheotomii skomentował na kartce: „Co wyście mi zrobili! Ale Totus Tuus”? Te, i inne sytuacje z życia świętego papieża są niejako ilustracją słów, które młody Karol Wojtyła włożył w usta głównego bohatera swojego dramatu (Brat naszego Boga), gdy ten w ostatniej scenie sztuki, patrząc na dzieło swojego życia, przyznał: „Wiem jednak, że wybrałem większą wolność” ${ }^{27}$.

Dla Karola Wojtyły - Jana Pawła II od wolności prosta droga prowadziła do miłości, zgodnie z przekonaniem, które wyraził w Częstochowie w 1987 roku: „Człowiek nie może być prawdziwie wolny, jak tylko przez miłośc” ${ }^{28}$. Temu trzeciemu wymiarowi antropologii, wymiarowi serca, Wadowiczanin poświęcił najwięcej czasu jako duszpasterz młodzieży, a potem jako duszpasterz rodzin w Krakowie. To duszpasterskie doświadczenie nie tylko sprawiło, że nauczył się „miłować ludzką miłość, ale i dało mu przekonanie, że: „Miłość nie jest do wyuczenia, a równocześnie nic nie jest tak bardzo do wyuczenia jak miłość!”29.

$\mathrm{W}$ książce pt. Miłość i odpowiedzialność, podejmując temat relacji między kobietą a mężczyzną, autor wyróżnił cztery rodzaje miłości: upodobania - akcentującą wymiar uczuć; pożądania - podkreślającą czynnik zmysłów; życzliwości związaną ze wspólnym światem wartości i przyjaźnią oraz oblubieńczą - polegającą na wzajemnym pełnym oddaniu się osób ${ }^{30}$. W swoim dziele Karol Wojtyła nie ograniczył się tylko do świata relacji damsko-męskich, lecz napisał także, że: „Osoba jest takim dobrem, że właściwe i pełnowartościowe odniesienie do niej stanowi tylko miłość" ${ }^{11}$ (tzw. norma personalistyczna). Bo choć Jan Paweł II do końca był promotorem małżeństwa i rodziny i sporo pism - z katechezami o teologii ciała, adhortacją Familiaris consortio i Listem do rodzin na czele - poświęcił związkowi kobiety i mężczyzny, to nieustannie podkreślał, że droga miłości obowiązuje każdego człowieka, a przykazanie miłości bliźniego dotyczy wszelkich relacji międzyludzkich. W pierwszej, programowej encyklice Redemptor hominis napisał:

${ }^{27}$ K. Wojtyła, Brat naszego Boga, [w:] K. Wojtyła, Jan Paweł II, Poezje, dramaty, szkice. Tryptyk rzymski, Kraków 2004, s. 392.

${ }^{28}$ Jan Paweł II, Homilia w czasie Mszy św. odprawionej w kaplicy Cudownego Obrazu, Częstochowa, 13.06.1987 [w:] Jan Paweł II, Pielgrzymki do ojczyzny..., dz. cyt., s. 507.

${ }^{29}$ Jan Paweł II, Przekroczyć próg nadziei, Lublin 1994, s. 103.

${ }^{30}$ K. Wojtyła, Miłość i odpowiedzialność, Lublin 1986, s. 69-92.

${ }^{31}$ K. Wojtyła, Miłość i odpowiedzialność, dz. cyt., s. 42. 
Człowiek nie może żyć bez miłości. Człowiek pozostaje dla siebie istotą niezrozumiałą, jego życie pozbawione jest sensu, jeśli nie objawi mu się Miłość, jeśli nie spotka się z Miłością, jeśli jej nie dotknie i nie uczyni w jakiś sposób swoją, jeśli nie znajdzie w niej żywego uczestnictwa. ${ }^{32}$

Powszechne powołanie do miłości dla Jana Pawła II łączyło się z byciem stworzonym na obraz i podobieństwo Trójcy Świętej (por. Rdz 1, 27-28), bytującej w wymiarze doskonałej komunii i wzajemnego daru. Papież przypominał o tej prawdzie za ojcami kapadockimi i Ryszardem od św. Wiktora, uzupełniając tym samym stanowisko św. Augustyna i św. Tomasza z Akwinu, którzy kwestię imago Dei sprowadzali do ludzkiej wolności i rozumności. W nowym humanizmie Jana Pawła II związek między poszukiwaniem samego siebie a spełnieniem siebie, właściwym dla osoby ludzkiej, wyrażony jest w sposób paradoksalny: człowiek „jest dla siebie”, wówczas, kiedy „daje siebie”. Tylko poprzez dar osiąga pełną realizację swojej zdolności bycia osobą, uaktualnienie swojej możności ${ }^{33}$.

Nie można jednak zapominać, że Jan Paweł II nie tylko przytaczał słowa o miłości, pogłębiał i rozważał je. Przede wszystkim żył nimi na co dzień. Sam swoim pięknym życiem zaświadczał o tym, że człowiek wówczas najbardziej jest sobą, kiedy daje siebie w darze dla innych. Ile to osób na całym świecie mogło przez ponad 27 lat jego posługi Piotrowej być odbiorcami jego niezwykłego „promieniowania ojcostwa”? Doświadczać na sobie spojrzenia miłości papieża z Polski czy słuchać takich zdań, jak to skierowane w 1987 roku do młodzieży w Tarnowie: „Przyjechałem z Rzymu, żeby wam tutaj życzyć dobrej nocy" ${ }^{34}$ ?

Na koniec, mając w pamięci nie tylko wielką miłość Karola Wojtyły - Jana Pawła II do ludzi wszystkich ras i narodów, ale i jego życie w czystej prawdzie i doskonałej wolności, możemy zapytać, skąd ojciec święty brał siłę do życia na miarę tej wielkiej antropologii, której sam był piewcą? I poszerzając perspektywę, jak człowiek XXI wieku ma realizować w życiu wzrastanie w wymiarze umysłu, woli i serca? Co zrobić, aby żyć na miarę nowego humanizmu, „bardziej być człowiekiem i chrześcijaninem, aby odkrywać i rozwijać w sobie talenty otrzymane od Stwórcy i realizować powołanie do świętości” ${ }^{35}$ ?

${ }^{32}$ Jan Paweł II, enc. Redemptor hominis, 10.

${ }^{33}$ Por. C. Caffarra, Prawda i płodność daru, [w:] Miłować ludzka miłość, Dziedzictwo myśli Jana Pawła II o małżeństwie i rodzinie, red. L. Melina, S. Grygiel, tłum. J. Skoczylas, K. Halat, Warszawa 2010, s. 186.

${ }^{34}$ Jan Paweł II, Słowo do młodzieży zgromadzonej przed siedzibą biskupa, Tarnów, 09.06.1987, [w:] Jan Paweł II, Pielgrzymki do ojczyzny, dz. cyt., s. 417.

${ }^{35}$ Jan Paweł II, Homilia w czasie liturgii słowa skierowana do młodzieży na placu Mickiewicza, Poznań, 03.06.1997, [w:] Jan Paweł II, Pielgrzymki do ojczyzny, dz. cyt., s. 921. 
Temu pytaniu wychodzą naprzeciw słowa, które Jan Paweł II wypowiedział w czasie wspomnianej homilii w Częstochowie z 1979 roku, będącej wszak drogowskazem dla niniejszych rozważań nad rolą prawdy, wolności i miłości w życiu człowieka. Papież mówił wówczas:

Praca nad sobą (...) jest jak najbardziej osobistą współpracą z Jezusem Chrystusem, na wzór tej, jaka dokonała się w uczniach, wybranych przez Niego, gdy zawezwał ich do swojej bliskości. Musicie o sobie myśleć w kategoriach uczniów Chrystusa. Chrystus wciąż ma uczniów, wszyscy jesteśmy Jego uczniami - jeżeli słuchamy Jego słowa, jeżeli je rozważamy, jeżeli sięgamy w głąb naszego serca, jeżeli Mu to serce otwieramy, jeżeli razem z Nim kształtujemy w sobie cierpliwie, wytrwale nowego człowieka. ${ }^{36}$

Oto punkt dojścia, a raczej zarazem i punkt wyjścia nowego humanizmu Jana Pawła II: „Jeden zwrot ducha, jeden kierunek umysłu, woli i serca: «ad Christum Redemptorem hominis, ad Christum Redemptorem mundi»"37.

Podsumowując, nie sposób nie zauważyć, że kształtowanie w sobie nowego człowieka, wybór większej wolności, życie na miarę nowego humanizmu w prawdzie, wolności i miłości, nie jest łatwe. A jednak papież w 1979 roku na spotkaniu z profesorami i studentami KUL-u przekonywał:

Jeszcze jedno wam powiem. Powiem wam, że ta droga ma swój urok. I wy wszyscy jesteście świadomi tego, że ta droga ma swój urok i swoje piękno. Ewangelia to jest droga pięknego życia człowieka albo też droga trudnego piękna życia ludzkiego. Życzę wam właśnie tej drogi, tego trudnego piękna życia ludzkiego. ${ }^{38}$

\section{Abstract \\ „Choosing greater freedom”. John Paul II's new humanism}

On October 19, 1986 in Florence, Pope John Paul II addressed a call to create a "new humanism". The Holy Father however, did not offer an in-depth analysis of the proposed concept.

This is not surprising to the researchers of his thoughts as often happened that the Pope did not explain the assumptions of the new proposed concepts. A similar situation

${ }^{36}$ Jan Paweł II, Homilia w czasie Mszy św. odprawionej dla alumnów, młodzieży zakonnej i stużby liturgicznej, dz. cyt., s. 114.

${ }^{37}$ Jan Paweł II, enc. Redemptor hominis, 7.

${ }^{38}$ Jan Paweł II, Przemówienie do profesorów i studentów Katolickiego Uniwersytetu Lubelskiego, Częstochowa, 06.06.1979, [w:] Jan Paweł II, Pielgrzymki do ojczyzny, dz. cyt., s. 132. 
occurred in the case of a call for "new evangelisation", "new feminism" or "new imagination of mercy".

The purpose of this article is to propose the key-words of the new humanism of John Paul II. The author bases her analysis both on philosophical and theological texts of Karol Wojtyła - John Paul II. According to her the new humanism of John Paul II is based on three dimensions: truth, freedom and love.

Keywords: John Paul II, new humanism, truth, freedom, love, antropology 
4. Uniwersytet Papieski

Pfog Jana Pawła II 